\title{
Simple re-framing unlikely to boost public support for climate policy
}

Thomas Bernauer and Liam F. McGrath

thbe0520@ethz.ch liam.mcgrath@ir.gess.ethz.ch

Ambitious policies for limiting climate change require strong public support ${ }^{1,3,12,15,16,19,20,29}$. But the public's appetite for such policies, as currently observed in most countries, is rather limited ${ }^{3,27}$. One possibility for enhancing public support could be to shift the main justification in the public policy discourse on greenhouse gas (GHG) mitigation from benefits of reducing climate change risks (the conventional justification) to other types of benefits. Technological innovation and green jobs, community building, and health benefits are widely discussed candidates $^{2,5,9,10,11,14,17,21,26}$. The intuition is that re-framing GHG mitigation efforts and their benefits in such terms could make them more personally relevant and more emotionally engaging and appealing to citizens ${ }^{28,25}$. However, based on results from two survey embedded experiments (combined $\mathrm{N}=1664$ ), and in contrast to some earlier studies, we conclude that simple re-framing of climate policy is unlikely to increase public support, and outline reasons for this finding. As the added value of other justifications remains unclear at best and potentially nil, sticking to climate risk reduction as the dominant justification seems worthwhile.

In many if not most countries, rapid progress towards a low carbon economy appears technically feasible, but politically impossible. Strong worries among elites and citizens about negative effects on economic growth and lifestyles, discounting of future benefits of greenhouse gas (GHG) emissions mitigation, and concerns about freeriding by other countries spoil the public's appetite for ambitious mitigation measures ${ }^{3}$. For instance, as observed in a recent survey, concern in the United States (the largest per capita GHG emitter globally) regarding climate change and its impact is the lowest among 40 countries in the study $^{27}$. However, without strong public support, ambitious climate policy is infeasible since mitigation measures are bound to have important and manifest implications for nearly every citizen. Therefore, democratic policy-makers face strong incentives to adopt policies preferred by the majority of voters ${ }^{3,29}$.

Current efforts to conceptualize climate policy in terms of preventing a tragedy of the commons (dangerous global warming) and focusing on fair burden sharing among nations to produce a global public good does not seem to win people's hearts and minds. The implications of modest to low domestic public support are obvious at the international level too: governments are locked into cumbersome distributional bargaining over lowest common denominator mitigation targets, and the enthusiasm in frontrunner countries (above all in Western Europe) also appears to wane.

How could public support and thus political feasibility at domestic and international levels be increased? Various scientists and commentators have suggested re-framing climate policy from an effort to reduce or avoid climate 
change risks to either an effort to accelerate a major technological transition that will foster innovation and create green jobs, or to an effort to protect the public from climate change-induced health hazards. Could such re-framing increase the public's appetite for ambitious climate policy?

Existing research has produced some evidence for such "emphasis framing effects" 6 , that is, effects on public opinion of highlighting particular purposes and benefits of reducing GHG emissions ${ }^{5,14}$. Building on this research (most notably $2,9,10,11,17,21,26$ ) we carried out two experiments (combined $\mathrm{N}=1664$ ) with participants from the United States (Figure 1).

Figure 1: Emphasis-Framing Experiments

\section{Treatments}

\begin{tabular}{l|l|}
\hline Experiment 1 & $\begin{array}{l}\text { Control Frame: } \\
\text { Climate risk reduction } \\
\text { Emphasising the risks and potential } \\
\text { catastrophes that failure to combat } \\
\text { climate change would lead to. }\end{array}$ \\
\hline Ex=1003 & $\begin{array}{l}\text { Economic Co-Benefits } \\
\text { Frame } \\
\text { Emphasising combatting climate change } \\
\text { would lead to technological innovation } \\
\text { and a more prosperous economy. }\end{array}$ \\
\hline $\begin{array}{l}\text { Good Society Frame } \\
\text { Emphasising combatting climate change } \\
\text { would foster community spirit. }\end{array}$ \\
\hline Experiment 2 & $\begin{array}{l}\text { Control Frame: } \\
\text { Climate risk reduction } \\
\text { Emphasising the risks and potential } \\
\text { catastrophes that failure to combat } \\
\text { climate change would lead to. }\end{array}$ \\
\hline $\begin{array}{l}\text { Health Benefits Frame } \\
\text { Emphasising how combatting climate } \\
\text { change would improve health through } \\
\text { pollution reduction and encouraging } \\
\text { more active lifestvles. }\end{array}$ \\
\hline
\end{tabular}

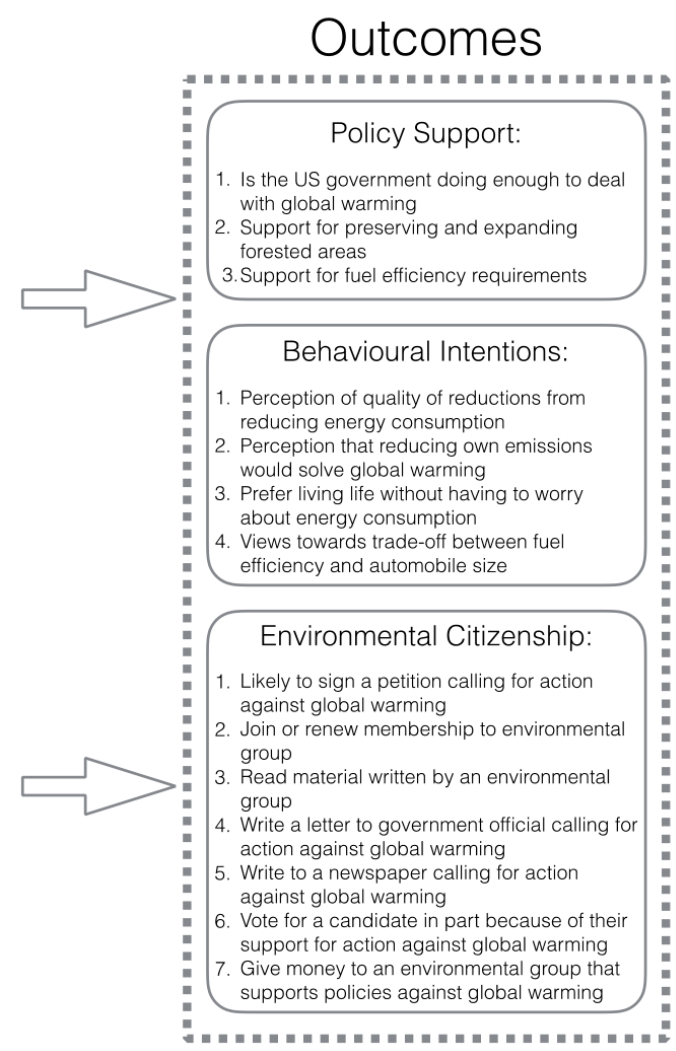

As illustrated in Figure 1, participants were randomly assigned to texts that justified (framed) climate policy in terms of having different types of benefits: climate risk reduction, economic co-benefits, community building, and health benefits respectively. Support (or opposition) to climate policy was measured based on three composite variables, each of which was constructed based on a set of survey items (see section 1 in the SI for full details).

The data shown in Figure 2 suggests interesting variation when the three measures are compared. Top-down efforts to mitigate climate change, as captured by the policy support measure, receive stronger support than requirements for citizens to become more actively engaged in mitigating GHG emissions, as captured by the behavioral intentions and environmental citizenship measures. Also, we find that those who do not believe climate change is a serious problem are overwhelmingly against active personal engagement. 
Nevertheless, a considerable share of these respondents support active climate policy by the government, suggesting some maneuvering room even amongst those who do not consider climate change to be a serious problem. Similarly, although respondents who believe climate change is a serious problem are strongly in favor of emissions mitigation policy, the responses for environmental citizenship are much more dispersed. This suggests that many respondents aware of the climate change problem would nevertheless prefer to be passive actors in climate policy. These trends are similar for other measures of climate skepticism and awareness (see section 6 of the SI).

Figure 2: Climate Policy Support: Distribution of three climate policy support measures in both experiments, conditional upon whether respondents believe climate change is a serious problem or not. The overall distribution is also shown for comparison.

1) Policy Support

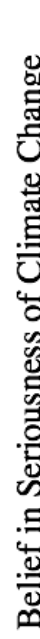

Climate Change Serious -
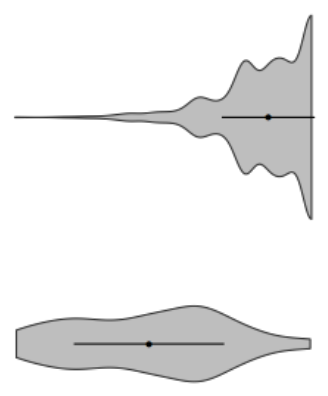

Climate Change Not Serious

苛

All Respondents

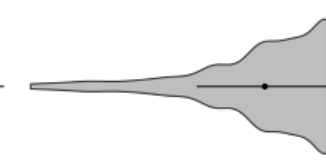

2) Behavioural Intentions
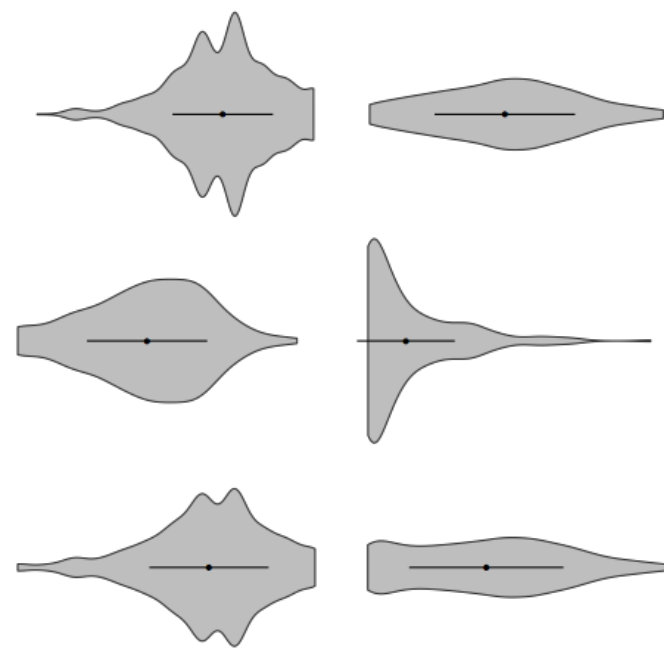

3) Environmental Citizenship
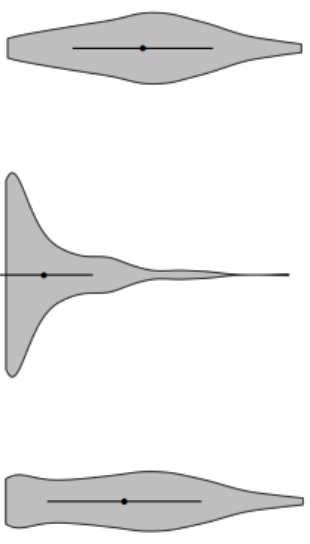

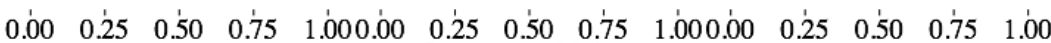
Outcome Value

Could emphasizing economic, community, and public health benefits engender more policy support for and active personal engagement in GHG mitigation, as measured by our three composite variables? Can such (re-)framing generate more support amongst those who are skeptical about whether climate change is a serious problem?

Previous research suggests that the effect of emphasis frames, as conceptualized in our study, could be stronger in the case of climate change skeptics ${ }^{2}$. Hence we use a range of survey items to identify individuals in terms of climate skepticism, climate awareness, and political ideology and examine conditional treatment effects (for details of the statistical analysis see section 5 of the SI).

As Figure 3 illustrates, there is very little difference across the treatment conditions in climate policy preferences overall. For each of the three 
experimental conditions, and each of the three outcome measures, there are no consistent patterns in treatment effects. The average treatment (framing) effects are very weak, and not statistically significant at conventional levels. Even when exploring potential subgroup effects, such as the differences between climate skeptics and non-skeptics, the treatment effects do not change significantly. Although there are some potentially large treatment effects in the case of policy support - for example amongst people who do not believe climate change is serious in the first experiment - these effects are negative. This result runs counter to the idea that these changes in framing can stimulate support for climate change mitigation amongst those predisposed against it. Even so, these effects are not statistically significant at conventional levels.

Figure 3: Framing Effects: Estimated average treatment effects and sub-group treatment effects based upon respondents' level of climate change skepticism, climate awareness, and party affiliation. Points indicate the estimated effect, lines indicate 95\% confidence intervals with the 90\% confidence interval in bold.
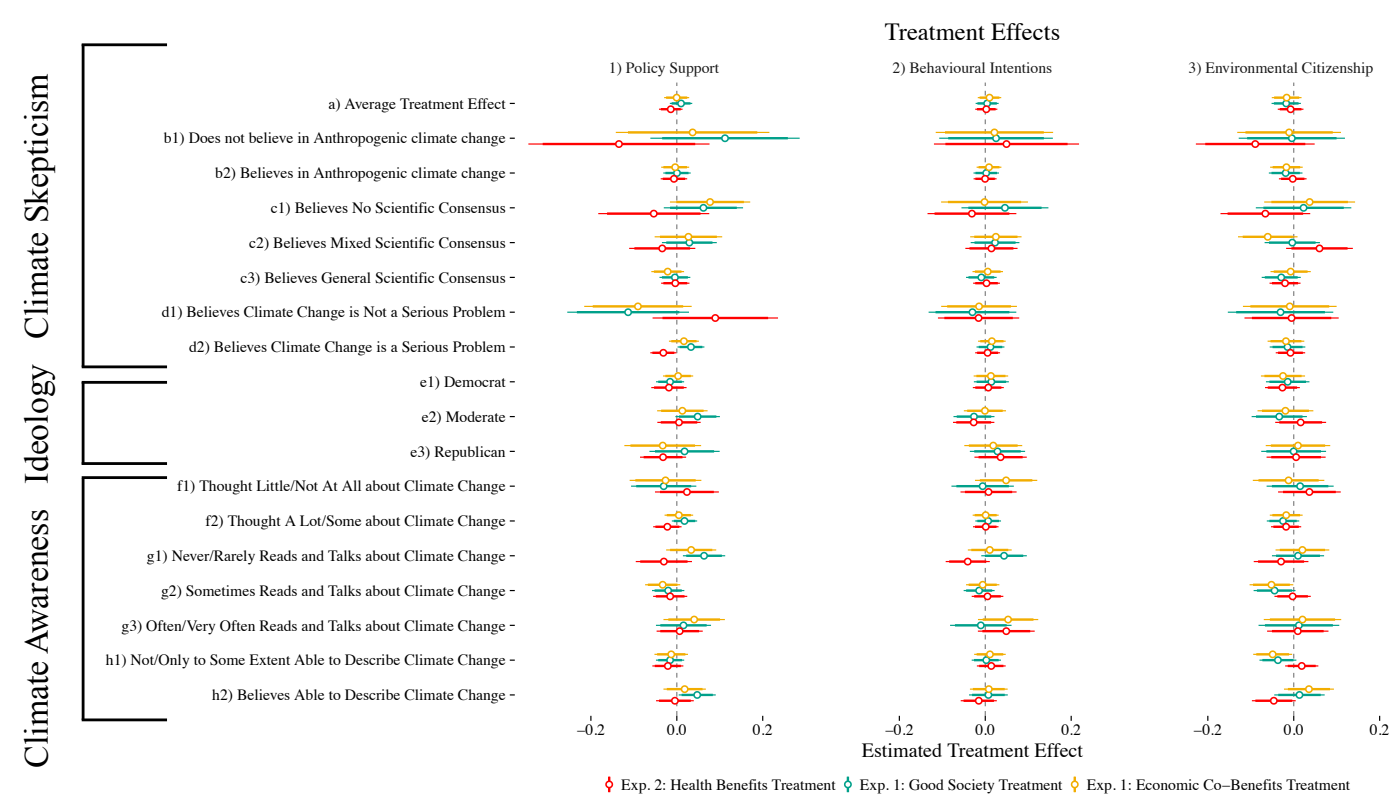

In summary, we do not find any robust empirical evidence for alternative framing (justification) of climate policy being able to increase public support for GHG mitigation - whether in the sample as a whole or amongst particular groups of participants (such as climate skeptics). This means that our findings do not support earlier results from what in our view is the most relevant prior study of a similar nature ${ }^{2}$. Framing effects are largely insignificant in those parts of our experiments that were deliberately designed to be very similar to the Bain et al. study (frame wording for climate risk, community building, economic co- 
benefits; environmental citizenship intentions, see Figure 1). The same result obtains when using different response measures that capture climate policy attitudes and preferences more directly, and adding an additional frame (health benefits).

Where does this leave us? Critics might argue that we simply failed to detect a treatment effect that does exist (often called "type II error"). One could of course modify the frame wordings (treatments) we used - we chose them because we found them quite compelling and they were partly used in a previously published article in this journal. And one could add visually more powerful graphical treatment conditions. Also, using a different sample from the United States or another country could potentially change the results. Although we cannot exclude this possibility, we think that our results reflect conditions that render it difficult, generally, to effectively shift public opinion on climate policy (and probably any environmental policy) through simple re-framing of policy justifications or benefits.

In reality, citizens are exposed to many competing claims (frames and counterframes) about costs and benefits of different climate policy measures and the need to act against climate change $e^{4,8,18,23,24}$. Depending on prior attitudes, knowledge and interest in climate issues (among other factors) individuals tend to select particular types of information on climate policy issues, as provided by the media, friends, and other sources. This information abundance means that, to varying degrees, survey participants are already "pre-treated" once they enter into a framing experiment. This makes identification of significant framing effects less likely, perhaps with the exception of people who know little about climate change and/or hold weak or ambivalent attitudes on the issue ${ }^{7}$. Hence it is not surprising that framing effects observed in other studies tend to be rather weak and inconsistent, probably with a tendency of many "non-findings" not getting published, and that in our own research such effects are largely absent.

Moreover, a large amount of research shows that climate policy preferences are strongly shaped by factors that cannot be affected or offset through climate change communication per se (e.g. political ideology, income, gender, general social norms, weather or climatic conditions, economic conditions of the respective country $1,12,15,16,19,20$. And it is precisely those factors that are likely to also influence (self-selected or involuntary) exposure to particular types of climate change information. Existing research shows that people usually select information lining up with prior beliefs and attitudes to preserve their existing worldviews, self-concept, and self-worth ${ }^{22}$, or to sustain beliefs that are in line with prevailing values, ideologies, and beliefs in their social network ${ }^{13}$.

In brief, there is sufficient evidence to presume that individuals' climate policy attitudes are strongly shaped by the pre-treatment environment and various personal predispositions, and that this tends to "immunize" experimental participants against simple information treatments.

So, what are the odds that shifting the main justification for greenhouse gas (GHG) mitigation from benefits of reducing climate change risks to other types of benefits would increase political support for and thus the political feasibility of ambitious GHG mitigation measures? Our findings point to major uncertainty in this regard, and to a need for more research based on more elaborate 
experimental designs. Such experiments would have to pitch particular frames and counter-frames against each other. They would have to focus on how different combinations of frames (rather than receiving a single frame as a treatment) affect public support. They would have to control for individuals' selfselection of information. Such experiments could also include visual frames, which might have a stronger effect than text messages.

Pending that, and based on what we know to date, policy-makers should keep a strong focus on climate risk reduction as the dominant justification. The reason is that time, money, political capital, and public attention, all of which are needed for re-framing the justification for climate policy in effective ways, are very much limited. This implies a considerable risk that much increased emphasis of other benefits, the public support increasing effect of which remains unclear, could come at the expense of the climate risk-based justification, into which the IPCC, the scientific community as a whole, and most governments and civil society have invested very heavily over the past decades.

\section{References}

1. Allo, M., Loureiro, M. L. 2014. "The Role of Social Norms on Preferences Towards Climate Change Policies: A Metaanalysis." Energy Policy 73:563574.

2. Bain, P. G. et al. 2012. "Promoting Pro-Environmental Action in Climate Change Deniers." Nature Climate Change 2: 600-603. See also: Bain, P. G. et al. (2015). "Co-benefits of addressing climate change can motivate action around the world." Nature Climate Change DOI: 10.1038/NCLIMATE2814.

3. Bernauer, T. 2013. "Climate Change Politics." Annual Review of Political Science 16: 421-448.

4. Boykoff, M.T. 2014. "Media Discourse on the Climate Slowdown." Nature Climate Change 4:156 - 158.

5. Drews, S., van den Bergh, J. 2015. "What Explains Public Support for Climate Policies? A Review of Empirical and Experimental Studies." Climate Policy, DOI: $10.1080 / 14693062.2015 .1058240$.

6. Druckman, J. N. 2001. "The Implications of Framing Effects for Citizen Competence." Political Behavior 23(3): 225-256.

7. Druckman, J. N., Leeper, T.J. 2012. "Learning More from Political Communication Experiments: Pretreatment and Its Effects." American Journal of Political Science 56(4): 875-896.

8. Elsasser, S.W., Dunlap, R.E. 2013. "Leading Voices in the Denier Choir: Conservative Columnists' Dismissal of Global Warming and Denigration of Climate Science." American Behavioral Scientist 57(6): 754-776.

9. Hardisty, D. J., Johnson, E. J., Weber, E. U. 2009. “A Dirty Word or a Dirty World? Attribute Framing, Political Affiliation, and Query Theory." Psychological Science 21: 86-92. 
10. Hart, P. S. 2011. "One or Many? The Influence of Episodic and Thematic Climate Change Frames on Policy Preferences and Individual Behavior Change." Science Communication 33: 28-51.

11. Hart, P. S., Nisbet, E. C. 2012. “Boomerang Effects in Science Communication How Motivated Reasoning and Identity Cues Amplify Opinion Polarization About Climate Mitigation Policies." Communication Research 39:701-723.

12. Kachi, A., Bernauer, T., Gampfer, R. 2015. "Climate Policy in Hard Times: Are the Pessimists Right?" Ecological Economics 114: 227-241,

13. Kahan, D.M; Peters, E; Wittlin, M; Slovic, P; Ouelette, L.L; Braman, D and G. Mandel. 2012. "The Polarizing Impact of Science Literacy and Numeracy on Perceived Climate Change Risks." Nature Climate Change 2: 732 - 735.

14. Lakoff, G. 2010. "Why it Matters How We Frame the Environment." Environmental Communication 4: 70-81.

15. Lam, S. P. 2014. "Predicting Support of Climate Policies by Using a Protection Motivation Model.” Climate Policy 15: 321-338.

16. Leiserowitz, A., Maibach, E., Roser-Renouf, C., Feinberg, G., Marlon, J., Howe, P. 2013. "Public Support for Climate and Energy Policies in April 2013." New Haven, CT: Yale Project on Climate Change Communication, Yale University and George Mason University.

17. Lockwood, M. 2011. "Does the Framing of Climate Policies Make a Difference to Public Support? Evidence from UK marginal constituencies." Climate Policy 11: 1097-1112.

18. Mayer, F.M. 2012. "Stories of Climate Change: Competing Narratives, the Media, and U.S. Public Opinion 2001-2010." Joan Shorenstein Center on the Press, Politics and Public Policy Discussion Paper Series \#D-72.

19. McCright, A. M., Dunlap, Riley E. 2011. "The Politicization of Climate Change and Polarization in the American Public's Views of Global Warming." The Sociological Quarterly 52:155-194.

20. McCright, Aaron M., Dunlap, R. E., Marquart-Pyatt, S. T. 2015. "Political Ideology and Views About Climate Change in the European Union." Environmental Politics 25:2, 338-358, DOI: 10.1080/09644016.2015.1090371.

21. Myers, T. A., et al. 2012. "A Public Health Frame Arouses Hopeful Emotions About Climate Change." Climatic Change 113: 1105-1112.

22. Nyhan, B., Reifler, J. "The Roles of Information Deficits and Identity Threat in the Prevalence of Misperceptions." 2015. MS. Yale University, n.p.

23. O’Neill S., Williams, H.T.P., Kurz T., Wiersma, B., Bookoff, M. 2015. Dominant frames in legacy and social media coverage of the IPCC Fifth Assessment Report. Nature Climate Change 5: 380-385.

24. Painter, J. 2011. "Poles apart: the International Reporting of Climate Scepticism." Oxford: Reuters Institute for the Study of Journalism. 
25. Parag, Y., Capstick, S., and Poortinga,W. 2011. "Policy attribute framing: A comparison between three policy instruments for personal emissions reduction." Journal of Policy Analysis and Management 30: 889-905.

26. Petrovic, N., Madrigano, J., and Zaval, L. 2014. "Motivating mitigation: When health matters more than climate change." Climatic Change 126: 245-254.

27. Stokes, B., Eike, R., Carle, J. 2015. "Global Concern about Climate Change, Broad Support for Limiting Emissions." Pew Research Centers Global Attitudes Project, 5 Nov. 2015.

28. Smith, N., Leiserowitz, A. 2013. "The Role of Emotion in Global Warming Support and Opposition." Risk Analysis 34(5): 937-948.

29. Stehr, N. "Climate Policy: Democracy is not an Inconvenience." Nature 525: 449-450. 


\section{Supplementary Materials for}

\section{"Simple re-framing unlikely to boost public support for climate policy"}

\section{Thomas Bernauer ${ }^{1}$ and Liam F. McGrath ${ }^{2}$}

This document provides details on:

1. The design of our survey experiments.

2. The platform used to recruit participants for our experiments.

3. Balance statistics comparing the socio-demographic characteristics and outcomes of respondents between the two surveys and control/treatment conditions.

4. The operationalization of variables for the statistical analysis.

5. The design of the statistical analysis to estimate treatment effects.

6. Additional results not included in the main paper.

Replication materials available at: http://dx.doi.org/10.7910/DVN/PRGOYQ

\section{Survey Design}

Participants completed an online survey on a platform created with Qualtrics (Qualtrics, http://www.qualtrics.com/). After the informed consent page, respondents were asked to respond to questions in the following order:

1. Pre-treatment questions about general awareness about global warming and their climate risk perceptions.

2. Random assignment to the control or one of the treatment conditions. Participants then read a passage with a randomly assigned frame.

3. All the items necessary to construct the three outcome measures.

4. Demographics (e.g. age, income, political ideology, etc.)

The survey items for our three outcome/response measures as noted in the main text (policy support, behavioral intentions, environmental citizenship intentions) are:

\footnotetext{
${ }^{1}$ Center for Comparative and International Studies \& Institute for Science, Technology and Policy, ETH Zurich, Zurich, Switzerland. Email: thbe0520@ethz.ch ${ }^{2}$ Center for Comparative and International Studies, ETH Zurich, Zurich, Switzerland. Email: liam.mcgrath@ir.gess.ethz.ch
} 
Table 1: Survey items used for the three outcome variables

(a) Policy attitudes regarding climate change mitigation

1. To deal with global warming, do you think the government of the U.S. is doing ...

2. Do you favor or oppose preserving or expanding forested areas, even if this means less land for agriculture or construction?

3. Do you favor or oppose increasing the requirements for fuel efficiency of automobiles, even if this raises the cost of cars and bus fares?
1 Too much

2 About the right amount

3 Not enough

4 Don't know

1 Favor strongly

2 Favor somewhat

3 Oppose somewhat

4 Oppose strongly

5 Don't know

1 Favor strongly

2 Favor somewhat

3 Oppose somewhat

4 Oppose strongly

5 Don't know

(b) Behavioral change intentions

1. If I had to reduce my energy consumption and carbon dioxide emissions this would reduce my quality of life too much.

2. If I avoid activities that emit carbon dioxide I contribute to solving the problem of global warming.

3. I prefer to enjoy life without having to worry about how much energy I consume and how much carbon dioxide I emit.

4. Imagine you are buying a new car and you have to choose between a larger, more powerful car that consumes more fuel, and a smaller and less powerful car that consumes less fuel. Assume that this will be the only car you own, and that both cars cost exactly the same. Which car would you buy?
1 Strongly agree

2 Mostly agree

3 Mostly disagree

4 Strongly disagree

Same as above

Same as above

1 Larger, more powerful car consuming more fuel 2 Smaller, less powerful car consuming less fuel 
(c) Environmental citizenship intentions (based on Bain et al.'s response variable items, but focused on global warming, rather than environmental protection in general)

Opinions among individuals and groups differ on whether addressing global warming is a key concern. How likely are you to engage in the following activities in the next twelve months?

[1 Not at all likely - 5 Very likely]

1. Sign a petition in support of actions against global warming?

2. Join or renew membership of an environmental group that demands stronger policies against global warming?

3. Read a newsletter, magazine or other publication written by an environmental group that demands stronger policies against global warming?

4. Write a letter or call your member of Parliament or another government official to support stronger policies against global warming?

5. Write to a newspaper in support of stronger policies against global warming?

6. If a local, state or Federal election was called, vote for a candidate at least in part because he or she was in favor of stronger policies against global warming?

7. Give money to an environmental group that supports stronger policies against global warming?

The full texts of our treatment conditions modeled after Bain et al. (2012) and Myers et al. (2012) are $^{3}$ :

\section{Table 2: Frames for Experiment 1}

\footnotetext{
Climate risk frame (Used as the control condition in the experiment):
}

It can be confusing with all the science that comes out about global warming. Many people say that reducing carbon dioxide emissions, which are regarded as the main cause of global warming, will stop the planet heating up, and most scientists seem to think that. I think that because there is general consensus among scientists we have to accept that global warming is real. I've been thinking about the impact of taking action on global warming, and I think the effects on the environment will be obvious - it follows from the science. We'd stop sea levels rising, reduce the chance of extreme weather like droughts and floods, and save plant and animal species. We would be less affected by food and water shortages, heat waves, flooding, and health issues that come with high temperatures. Reducing carbon emissions would certainly reduce these risks from global warming, and that would be a good pay-off.

${ }^{3}$ A key difference between our treatment wording and that of Bain et. al (2012) is that we remove the reference to Al Gore from the original statements, as this would evoke strong partisan effects in the USA. 
Good Society frame (Corresponds to Bain et al.'s "Warmth" frame):

It can be confusing with all the science that comes out about global warming. But it got me thinking about what the world would be like if everyone pulled together to reduce carbon dioxide emissions, which are regarded as the main cause of global warming. It might stop global warmingwho knows? But I think one thing it would do for sure is affect who we are as people. People focus on the environmental effects of action on global warming, but that's not how I see it. I think about how taking action would impact the community, and on balance I think it would be good. Taking action to reduce carbon dioxide emissions would help us become more aware of how we live and how we impact on each other. I think it'd make us more considerate in other ways - like looking out for each other, and caring for people in the community. Who knows what it would do against global warming, but I think it'd make for a community where people are less selfish and more considerate in the long run, and that would be a good pay-off.

Economic Co-Benefits frame (Corresponds to Bain et al.'s "Development" frame):

It can be confusing with all the science that comes out about climate change. But it got me thinking about what the world would be like if everyone pulled together to reduce carbon dioxide emissions, which are regarded as the main cause of global warming. It might stop global warming - who knows? But I think one thing it would do for sure is affect our economy. People focus on the environmental effects of action on global warming, but that's not how I see it. I think about how taking action would impact the economy, and on balance I think it would be good. Taking action to reduce carbon dioxide emissions would lead to new scientific breakthroughs and new industries, leading to new jobs and more sustainable economic development. Who knows what it would do against global warming, but I think it'd make for a more prosperous and successful economy in the long run, and that would be a good pay-off.

Our second experiment is informed by a previous experiment by Myers et al (2012), which found that framing climate change mitigation in terms of its public health benefits elicited positive emotional responses amongst participants. The second experiment is identical to the first except we now use a public health frame, to see if this effect can be observed with the three outcome measures we are interested in. Table 3 displays the public health frame wording we used in our experiment. ${ }^{4}$

Table 3: Frames for Experiment 2

\footnotetext{
${ }^{4}$ We modified Myers et al.'s Public Health frame to keep the statement length and structure similar to that of the three other conditions.
} 
Climate risk frame (Used as the control condition in both experiments):

It can be confusing with all the science that comes out about global warming. Many people say that reducing carbon dioxide emissions, which are regarded as the main cause of global warming, will stop the planet heating up, and most scientists seem to think that. I think that because there is general consensus among scientists we have to accept that global warming is real. I've been thinking about the impact of taking action on global warming, and I think the effects on the environment will be obvious - it follows from the science. We'd stop sea levels rising, reduce the chance of extreme weather like droughts and floods, and save plant and animal species. We would be less affected by food and water shortages, heat waves, flooding, and health issues that come with high temperatures. Reducing carbon emissions would certainly reduce these risks from global warming, and that would be a good pay-off.

\section{Health Benefits frame:}

It can be confusing with all the science that comes out about global warming. But it got me thinking about what the world would be like if everyone pulled together to reduce carbon dioxide emissions, which are regarded as the main cause of global warming. It might stop global warming - who knows? But I think one thing it would do for sure is make us healthier. People focus on the environmental effects of action on global warming, but that's not how I see it. I think about how taking action would improve our health, and on balance I think it would be good. Taking action to reduce carbon dioxide emissions would help us redesign our cities and towns to make it easier and safer to travel by foot, bicycle and public transportation. This will reduce the number of cars on the road and will reduce traffic injuries and fatalities. It will help people become more physically active, lose weight, strengthen their bones, and possibly even to remain mentally sharp as they age. And using cleaner forms of energy-such as solar and wind power-will reduce air and water pollution, thereby preventing many forms of illness. Who knows what it would do against global warming, but I think it'd make for a healthier society in the long run, and that would be a good pay-off.

Table 4 shows the other items we used in the survey.

Table 4: Additional items in the survey 
Part 1 General interest and knowledge about climate change and climate policy, and global warming risk perception

Attention/interest in climate policy issues

How much had you thought about global warming before today?

A lot, some, a little, not at all

Do you feel you would be able to describe in very simple terms to another person what the problem of global warming is?

Yes, To some extent, No

How often do you watch, listen to, or read news media reporting on global warming or discuss the issue with colleagues, friends, or family?

Never, rarely, sometimes, often, very often

\section{Global warming risk perception}

Note: in our survey experiments, the order of this "risk" block and the control/treatment condition (coming up in the next part) was randomized across respondents to avoid potential contamination by an unintended risk priming effect.

In your view, is global warming, also known as climate change, a very serious problem, a somewhat serious problem, a not too serious problem, or not a problem?

1 Very serious problem

2 Somewhat serious problem

3 Not too serious problem

4 Not a problem

5 Don't know

When coal, oil, natural gas, or other fossil fuels are burned for energy, this releases carbon dioxide. Some say that these carbon dioxide emissions are causing global warming and more extreme weather events. Others say that changes in global temperatures and weather are happening for other reasons and have little to do with emissions of carbon dioxide by people. What is your view? Do you think that emissions of carbon dioxide are ...

1 Causing global warming

2 Contributing a little bit to global warming

3 Not causing global warming

4 Don't know

On the subject of global warming, is it your impression that among the scientists of the world ... 1 Most scientists think the problem is urgent and enough is known to take action

2 Most scientists think the problem is not urgent, and not enough is known yet to take action

3 Views are evenly divided among scientists

4 Don't know

Part 2 Control and treatment conditions

[See Tables 2 and 3 above.]

Part 3 Items used to construct the three outcome variables

[See Table 1 above.]

Part 4 Demographic questions

Are you male or female?

1 Male

2 Female

What racial or ethnic group best describes you? 


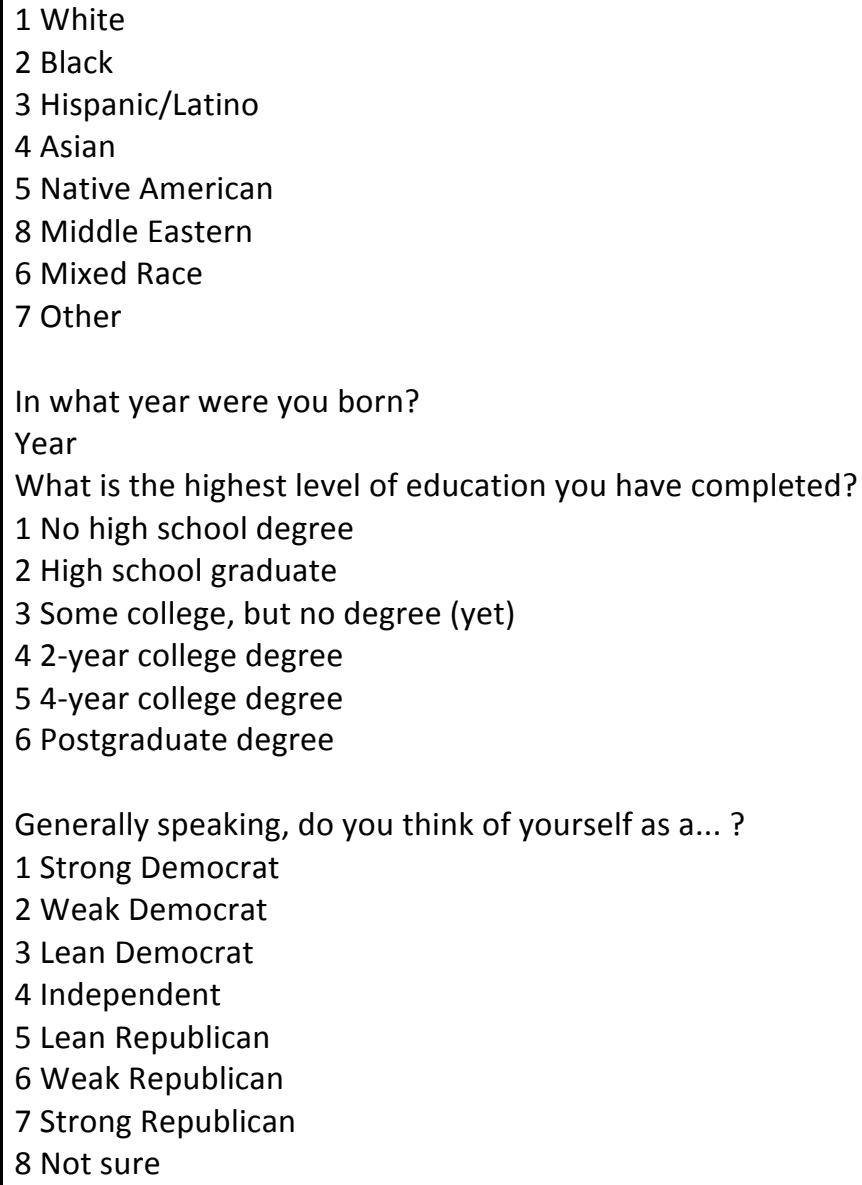


$10 \$ 100,000$ - \$119,999

$11 \$ 120,000$ - \$149,999

$12 \$ 150,000$ - \$199,999

$13 \$ 200,000$ - \$249,999

$14 \$ 250,000-\$ 349,999$

$15 \$ 350,000$ - \$499,999

$16 \$ 500,000$ or more

17 Prefer not to say

What is your current job?

(Open) 


\section{Survey Recruitment and Comparison to US Population}

Our survey experiments were conducted in two sets. What we here refer to as Experiment 1 evaluates the average treatment effect of the Community-Building and Economic Co-Benefits frames, compared to the effect of the Climate Risk frame (control). What we call Experiment 2 evaluates the average treatment effect of the Public Health frame, compared to the Climate Risk frame.

Experiment 1 was carried out in March 2014, and Experiment 2 was carried out in August 2014. Both were online survey experiments. We recruited participants in the United States via a crowd-sourcing platform, Amazon Mechanical Turk (AMT, http://aws.amazon.com/mturk/) (Amazon Mechanical Turk 2012). This means that our sample of participants is a convenience sample, which is appropriate for a study interested in treatment effects, but not for estimating the proportion of citizens in the US who support or oppose climate change policy, for instance. Therefore while our estimated treatment effects are internally valid, we should be cautious about external validity.

Nevertheless, it is reassuring for our research that the socio-demographics of the AMT population and samples drawn from that population are well studied in the literature. It has been shown that the demographic distributions of typical AMTrecruited samples are not very different (compared to national statistics) from samples obtained through traditional surveys, such as mail-in or random-digit phone based surveys (e.g., Amazon Mechanical Turk, 2012; Berinsky et al., 2012; Mason and Suri, 2012; Ross et al., 2010). Recent research has also shown that Mechanical Turk samples closely resemble the psychological divisions of liberals and conservatives drawn from representative samples (Clifford, Jewell and Waggoner 2015). Furthermore research comparing treatment effects between nationally representative and convenience samples finds that both show similar results (Mullinix et al. 2015). This suggests that the results obtained in our study, and particularly the treatment effects in which we are primarily interested, would remain similar to what traditional survey recruitment would have produced, within standard margins of error.

Table 5 displays socio-demographic distributions for ideology (liberal vs. conservative), education, income, gender and age for our sample and the US population (based on census data). The comparison shows that our sample tends to be somewhat more liberal, younger, better educated and composed of more men than the US population. For income the sample is close to the US population data. 
Table 5: Socio-demographic characteristics of our sample (USA) compared to population data

\begin{tabular}{|c|c|c|c|}
\hline & Our sample & Population & $\begin{array}{l}\text { Source of } \\
\text { population data }\end{array}$ \\
\hline \multirow[t]{2}{*}{ Ideology } & Liberal: 49\% & Liberal: $34 \%$ & $\begin{array}{l}\text { ANES 2008-2009 } \\
\text { Panel study }\end{array}$ \\
\hline & Conservative: $20 \%$ & Conservative: $45 \%$ & \\
\hline \multirow[t]{7}{*}{ Education } & No High School degree: $0.8 \%$ & Less than 9 th grade: $5 \%$ & U.S. Census \\
\hline & & $\begin{array}{l}\text { 9th to } 12 \text { th grade, no } \\
\text { diploma: } 8 \%\end{array}$ & Bureau, Current \\
\hline & High school graduate: $11.4 \%$ & High school graduate: & Population \\
\hline & $\begin{array}{l}\text { Some college but no degree } \\
\text { yet: } 33.3 \%\end{array}$ & $31 \%$ & $\begin{array}{l}\text { Survey, } \\
\text { November } 2008\end{array}$ \\
\hline & Associate degree: 9.9\% & $\begin{array}{l}\text { Some college or } \\
\text { associate's degree: } 28 \%\end{array}$ & \\
\hline & Bachelor: $34.9 \%$ & Bachelor's degree: $18 \%$ & \\
\hline & $\begin{array}{l}\text { Graduate (Master, PhD, } \\
\text { Professional degree/MD): } \\
9.8 \%\end{array}$ & Advanced degree: $9 \%$ & \\
\hline Income & $\begin{array}{l}\text { The median category in our } \\
\text { sample is: Category } 5 \$ 40,000 \\
\text { - } \$ 49,999\end{array}$ & $\begin{array}{l}\text { The } 2013 \text { U.S. median } \\
\text { house- hold income was } \\
\$ 52,250\end{array}$ & $\begin{array}{l}\text { U.S. Census } \\
\text { Bureau: total } \\
\text { median } \\
\text { income for } \\
\text { household } \\
\text { Retrieved April } \\
2015\end{array}$ \\
\hline Gender & $1.65 \mathrm{~m} / \mathrm{f}$ ratio & $\begin{array}{l}\text { Total population: } 0.97 \mathrm{~m} / \mathrm{f} \\
\text { ( } 2011 \text { est.) }\end{array}$ & $\begin{array}{l}\text { The World } \\
\text { Factbook (CIA) }\end{array}$ \\
\hline Age & Median age: 29 & Median age: 37.8 years & $\begin{array}{l}\text { The World } \\
\text { Factbook (CIA) }\end{array}$ \\
\hline
\end{tabular}

These differences are worth noting, but do not affect the internal validity of our analysis,as we focus on the effects of emphasis frames and not on inferences about climate change attitudes and preferences of the US population per se. This also means that we do not apply 
statistical weighting techniques to "correct" for differences between the socio-demographic distributions in our sample and the distributions captured by census data, as would be required for making inferences concerning the entire population of a country.

\section{Balance Statistics}

As previously mentioned, our survey experiments were conducted in two rounds. Experiment 1 compares the Climate Risk (control) condition with either the Good Society or Economic Co-Benefits conditions. Experiment 2 compares the Climate Risk (control) condition with the Health Benefits condition. Even though in each experiment respondents were randomly assigned either to the control or a treatment group, one might worry that the pool of respondents who accessed our survey experiments through AMT might be significantly different between the two sets of surveys, making direct comparison of the treatment effects less conclusive.

Table 6 summarizes the results of the two-sample t-tests. On four of the five main demographic characteristics-gender, education, partisanship, and income, the null hypothesis, that the mean scores of the two samples are the same, cannot be rejected at conventional significance levels. This means that the two samples are very similar on these three dimensions. However, in terms of age, Experiment 1 respondents turn out to be on average, about 2 years older.

These balance tests show that the two samples are balanced along the main demographic characteristics, except the age variable. However, this age difference is not substantial: in Experiment 1 the mean is 33.1 and Experiment 2 the mean is 31 . We do not see a theoretical reason why this small difference in mean age should influence the treatment effects systematically. Therefore, we conclude that it is safe to directly compare the treatment effects between experiments.

Table 6. Balance statistics: comparison of the mean demographics between Experiments 1 and 2

\begin{tabular}{|c|c|c|c|}
\hline & Experiment 1 & Experiment 2 & Two-sample t-test* \\
\hline $\begin{array}{l}\text { Female } \\
\text { (N) }\end{array}$ & $\begin{array}{c}1.38 \\
(1003)\end{array}$ & $\begin{array}{l}1.37 \\
(672)\end{array}$ & $\begin{array}{l}0.86 \\
\text { Difference not statistically significant }\end{array}$ \\
\hline $\begin{array}{l}\text { Age } \\
\text { (N) }\end{array}$ & $\begin{array}{c}32.9 \\
(1003)\end{array}$ & $\begin{array}{l}30.8 \\
(672)\end{array}$ & $\begin{array}{l}0.0001 \\
\text { Exp } 1 \text { is older on average. Significance at the } \\
99 \% \text { level }\end{array}$ \\
\hline $\begin{array}{l}\text { Education } \\
\text { (N) }\end{array}$ & $\begin{array}{c}3.97 \\
(1003)\end{array}$ & $\begin{array}{l}3.95 \\
(672)\end{array}$ & $\begin{array}{l}0.75 \\
\text { Difference not statistically significant }\end{array}$ \\
\hline $\begin{array}{l}\text { Party ID } \\
\text { (N) }\end{array}$ & $\begin{array}{c}3.51 \\
(1003)\end{array}$ & $\begin{array}{c}3.49 \\
(672)\end{array}$ & $\begin{array}{l}0.83 \\
\text { Difference not statistically significant }\end{array}$ \\
\hline $\begin{array}{l}\text { Income } \\
(\mathrm{N})\end{array}$ & $\begin{array}{l}5.56 \\
(981)\end{array}$ & $\begin{array}{l}5.67 \\
(644)\end{array}$ & $\begin{array}{l}0.51 \\
\text { Difference not statistically significant }\end{array}$ \\
\hline
\end{tabular}


The five socio-demographic variables are:

Age: ranging between 18 and 76 .

Female: a dichotomous variable of 1 for male and 2 for female.

Education: a 6-point scale of 1 (no high school degree), 2 (high school graduate), 3 (some college but no degree (yet)), 4 (2-year college degree), 5 (4-year college degree), 6 (postgraduate degree).

Party ID: a 7-point scale (as in the American National Election Studies (ANES)) of 1 (strong Democrat), 2 (weak Democrat), 3 (lean Democrat), 4 (Independent), 5(lean Republican), 6 (weak Republican), 7 (strong Republican).

Income: a 16-point scale of yearly household incomes from 1 (less than $\$ 10,000), 2$ $(\$ 10,000-\$ 19,000), \ldots$ to $16(\$ 500,000$ or more $)$.

We also examine balance statistics across all control and treatment groups. This is a stronger test to ensure that there is no systematic difference between respondents' characteristics based upon our treatment conditions, and assess whether the randomization was successful. We use one-way ANOVA tests, with the null hypothesis being that the mean scores across all control and treatment groups are equal. If we fail to reject the null hypothesis, then we can be reasonably sure that our random assignment of treatments was successful and the respondent characteristics in all groups are the same, making it safer to compare the treatment effects.

Again, other than for age, the across-group mean differences are not statistically significant with respect to four of the demographic characteristics, suggesting that random assignment of the control and treatment groups was mostly successful in our experiments (Table 7). In terms of the average age, a one- way ANOVA test without the Health condition shows that the inter-group means are statistically indistinguishable across the other four groups. Therefore, overall, we are quite confident that random assignment was successful and we can make meaningful comparisons of treatment effects. 
Table 7. Balance statistics across control and treatment groups

Experiment 1

Experiment 2

One-way ANOVA test*

\begin{tabular}{|c|c|c|c|}
\hline $\begin{array}{c}\text { Control } \\
\text { (Climate } \\
\text { Risk) }\end{array}$ & $\begin{array}{c}\text { Good } \\
\text { Society }\end{array}$ & $\begin{array}{c}\text { Economic } \\
\text { Co- } \\
\text { Benefits }\end{array}$ & $\begin{array}{c}\text { Control } \\
\text { (Climate } \\
\text { Risk) }\end{array}$ \\
\hline
\end{tabular}

\begin{tabular}{|c|c|c|c|c|c|c|}
\hline Female & 1.38 & 1.40 & 1.35 & 1.39 & 1.35 & 0.67 \\
\hline$(\mathrm{N})$ & (320) & (355) & (328) & (336) & (336) & $\begin{array}{l}\text { Difference not } \\
\text { significant }\end{array}$ \\
\hline Age & 33.3 & 32.7 & 32.8 & 32.0 & 29.6 & 0.0001 \\
\hline (N) & (320) & (355) & (328) & (336) & (336) & $\begin{array}{l}\text { Difference significant at } \\
\text { the } 95 \% \text { confidence }\end{array}$ \\
\hline Education & 3.89 & 3.94 & 4.07 & 4.03 & 3.87 & 0.18 \\
\hline$(\mathrm{N})$ & (320) & (355) & (328) & (336) & (336) & $\begin{array}{l}\text { Difference not } \\
\text { significant }\end{array}$ \\
\hline Party ID & 3.37 & 3.64 & 3.49 & 3.43 & 3.54 & 0.33 \\
\hline$(N)$ & (320) & (355) & (328) & (336) & (336) & $\begin{array}{l}\text { Difference not } \\
\text { significant }\end{array}$ \\
\hline Income & 5.36 & 5.65 & 5.70 & 5.71 & 5.64 & 0.54 \\
\hline (N) & (314) & (349) & (318) & (316) & (328) & $\begin{array}{l}\text { Difference not } \\
\text { significant }\end{array}$ \\
\hline
\end{tabular}

*Probability that the $\mathrm{F}$ score exceeds the critical value at the $95 \%$ confidence level.

**The average age of the first four groups are statistically equivalent ( $p$-value 0.55 .)

; only the last group has a significantly lower average age.

Given that we conducted two different experiments we also examine whether there are differences in the responses for the outcome variables between the two control groups. Table 8 displays the results of One-way ANOVA tests for each of the three outcome variables. The results show that there is not a statistically significant difference in the environmental citizenship and behavioural intention variables at conventional levels, however there is for the policy support variable. In this case the mean of the outcome for the control group in experiment 2 is 0.04 higher than in experiment 1 . Whilst this difference is statistically significant, it is not substantially large, corresponding to approximately 0.18 of the pooled standard deviation for the control groups. 
Table 8: Balance in outcome measures between control groups in the two experiments

\begin{tabular}{|c|c|c|c|}
\hline & $\begin{array}{l}\text { Experiment } 1 \\
\text { Control (Climate } \\
\text { Risk) }\end{array}$ & $\begin{array}{l}\text { Experiment } 2 \\
\text { Control (Climate } \\
\text { Risk) }\end{array}$ & One-way ANOVA test* \\
\hline $\begin{array}{l}\text { Environmental } \\
\text { Citizenship }\end{array}$ & $\begin{array}{c}0.39 \\
(n=320)\end{array}$ & $\begin{array}{c}0.42 \\
(n=336)\end{array}$ & 0.11 \\
\hline Policy Support & $\begin{array}{c}0.77 \\
(n=320)\end{array}$ & $\begin{array}{c}0.81 \\
(n=336)\end{array}$ & 0.03 \\
\hline $\begin{array}{l}\text { Behavioral } \\
\text { Intentions }\end{array}$ & $\begin{array}{c}0.63 \\
(n=320)\end{array}$ & $\begin{array}{c}0.64 \\
(n=336)\end{array}$ & 0.51 \\
\hline
\end{tabular}

*Probability that the $\mathrm{F}$ score exceeds the critical value at the $95 \%$ confidence level.

Given that we conducted two different experiments we also examine whether there are differences in the responses for the outcome variables between the two control groups.

\section{Operationalization of Variables}

Each of our three outcome variables is constructed from multiple survey items, in order to better measure preferences in these three areas. We use confirmatory factor analysis (CFA), as this is a principled way to aggregate multiple items into a consistent index. This helps alleviate potential measurement errors, and also improves construct validity of the outcome measures. This consideration is particularly relevant when the targeted measure is multi-faceted or not directly observed.

We conduct the CFA using polychoric correlations, as our survey items are ordinal and not continuous in their level of measurement. ${ }^{5}$

\footnotetext{
${ }^{5}$ More specifically we use the polychoric function in Stata to estimate the CFA.
} 
Table 9: Results of confirmatory factor analysis (CFA) for the outcome variables

\begin{tabular}{|c|c|c|c|c|c|c|}
\hline Latent variable & $\begin{array}{l}\text { Indicators } \\
\text { (Items) }\end{array}$ & $\mathrm{N}$ & $\begin{array}{l}\text { Cronbach's } \\
\text { alpha }\end{array}$ & Eigenvalue* & $\begin{array}{l}\text { Factor } \\
\text { loadings }\end{array}$ & Uniqueness \\
\hline Policy & & 1502 & 0.77 & 1.58 & & \\
\hline \multirow[t]{3}{*}{ Attitude } & 1 & & & & 0.73 & 0.46 \\
\hline & 2 & & & & 0.66 & 0.56 \\
\hline & 3 & & & & 0.78 & 0.39 \\
\hline Behavioral- & & 1663 & 0.67 & 1.37 & & \\
\hline Change & 1 & & & & 0.48 & 0.76 \\
\hline \multirow[t]{3}{*}{ Intentions } & 2 & & & & 0.52 & 0.73 \\
\hline & 3 & & & & 0.68 & 0.53 \\
\hline & 4 & & & & 0.64 & 0.60 \\
\hline Environmental & & 1663 & 0.95 & 4.76 & & \\
\hline Citizenship & 1 & & & & 0.83 & 0.27 \\
\hline \multirow[t]{6}{*}{ Intentions } & 2 & & & & 0.87 & 0.22 \\
\hline & 3 & & & & 0.75 & 0.41 \\
\hline & 4 & & & & 0.87 & 0.18 \\
\hline & 5 & & & & 0.82 & 0.23 \\
\hline & 6 & & & & 0.80 & 0.30 \\
\hline & 7 & & & & 0.82 & 0.30 \\
\hline
\end{tabular}

The results of the CFA mostly support our conceptualization of the composite environmental/support measures. As can be seen in Table 9, most factor loadings are in the conventional acceptable range of 0.6-0.9 (except two items that belong to Behavioral Change Intentions), and the Cronbach's alpha value is also mostly above the conventional acceptance level of 0.7 (except Behavioral Change Intentions). Overall, by conventional standards the first two outcome variables turned out excellent and our Behavioral Change measure turns out to be weaker than we 
theorized. Since the indicators (both the alpha and loadings) are not very far from conventional thresholds and we believe all the items we included for this measure are theoretically relevant, we decided to keep this variable as it is, instead of using the method for more exploratory purposes.

After carrying out the CFAs, the latent Environmental Citizens, Policy Attitude and Behavioral Intentions variables were constructed by regression methods, using the weights suggested by the CFAs for each survey items.

We also recode the questions used for sub-group analysis to ensure that we have a large enough group of respondents within each category to reliably estimate treatment effects. Table 10 below displays the recoded categories used for the statistical analysis of heterogeneous treatment effects.

Table 10: Recoding of survey items undertaken for the statistical analysis

\begin{tabular}{|c|c|c|}
\hline Concept & Original Categories & $\begin{array}{l}\text { Recoded Categories for } \\
\text { Statistical Analysis }\end{array}$ \\
\hline $\begin{array}{l}\text { b) Belief in Anthropogenic } \\
\text { Climate Change }\end{array}$ & $\begin{array}{l}1 \text { Causing global warming } \\
2 \text { Contributing a little bit to } \\
\text { global warming } \\
3 \text { Not causing global warming } \\
4 \text { Don't know }\end{array}$ & $\begin{array}{l}1 \text { Does not believe in } \\
\text { Anthropogenic climate change } \\
\text { (category 3) } \\
2 \text { Believes in Anthropogenic } \\
\text { climate change (category 1-2) } \\
\text { Category } 4 \text { (don't know) } \\
\text { excluded from analysis. }\end{array}$ \\
\hline $\begin{array}{l}\text { c) Belief in Scientific Consensus } \\
\text { regarding Climate Change }\end{array}$ & $\begin{array}{l}1 \text { Most scientists think the } \\
\text { problem is urgent and enough } \\
\text { is known to take action } \\
2 \text { Most scientists think the } \\
\text { problem is not urgent, and not } \\
\text { enough is known yet to take } \\
\text { action } \\
3 \text { Views are evenly divided } \\
\text { among scientists } \\
4 \text { Don't know }\end{array}$ & $\begin{array}{l}1 \text { Believes no scientific } \\
\text { consensus (category 2) } \\
2 \text { Believes mixed scientific } \\
\text { consensus (category } 3 \text { ) } \\
3 \text { Believes general scientific } \\
\text { consensus (category } 1 \text { ) } \\
\text { Category } 4 \text { (don't know) is } \\
\text { excluded from analysis. }\end{array}$ \\
\hline $\begin{array}{l}\text { d) Belief in Climate Change } \\
\text { being a serious problem }\end{array}$ & $\begin{array}{l}1 \text { Very serious problem } \\
2 \text { Somewhat serious problem } \\
3 \text { Not too serious problem } \\
4 \text { Not a problem } \\
5 \text { Don't know }\end{array}$ & $\begin{array}{l}1 \text { Climate Change is not a } \\
\text { serious problem (categories } 3 \\
\text { and } 4 \text { from question) } \\
2 \text { Climate Change is a serious } \\
\text { problem (categories } 1 \text { and } 2 \\
\text { from question) } \\
\text { Category } 5 \text { (don't know) is } \\
\text { excluded from analysis. }\end{array}$ \\
\hline
\end{tabular}


e) Political Ideology

$\begin{array}{ll} & 2 \text { Weak Democrat } \\ & 3 \text { Lean Democrat } \\ & 4 \text { Independent } \\ & 5 \text { Lean Republican } \\ & 6 \text { Weak Republican } \\ & 7 \text { Strong Republican } \\ & 8 \text { Not sure } \\ & 1 \text { A lot } \\ \text { f) Frequency of thought about } & 2 \text { some } \\ \text { Climate Change } & 3 \text { a little } \\ & 4 \text { not at all }\end{array}$

g) Frequency of reading and talking about Climate Change

h) Belief in ability to describe Climate Change
1 Never

2 rarely

3 sometimes

4 often

5 very often

1 Yes

2 To some extent

3 No
1 Democrat (categories 1-3)

2 Moderate (category 4)

3 Republican (categories 5-7)

Category 8 (not sure) is

excluded from analysis.

1 Thought little/not at all about climate change (categories 3-4) 2 Thought a lot/some about climate change (categories 1-2)

$1 \mathrm{Never} /$ rarely reads and talks about climate change

(categories 1-2)

2 Sometimes reads and talks about climate change (category 3)

3 Often/very often reads and talks about climate change (categories 4-5)

1 Believes not or only to some extent able to describe climate change (categories 2-3) 2 Believes able to describe climate change (category 1 )

\section{Design of the Statistical Analysis}

We use regression analysis (OLS) to estimate the treatment effects displayed in the paper. To estimate the group specific treatment effects, i.e. the treatment effect for those who do not believe climate change is serious, we include multiplicative terms between the treatments and the groups. This is done for all groups in the same model, to increase the validity of claims that membership in a particular group affects the treatment effect and not that this group membership is associated with other factors that may affect the treatment effect. ${ }^{6}$ After estimation, we use the observed value approach (Hanmer and Kalkan 2013) to generating the treatment effects displayed in Figure 3 in the main text. ${ }^{7}$

\footnotetext{
${ }^{6}$ This is because unlike the treatments, group membership is not randomly assigned. Therefore the usual logic of control variables in observational studies is needed to reliably estimate group specific/heterogeneous treatment effects.

${ }^{7}$ These are computed using the margins command in Stata.
} 


\section{Additional Results}

In the main text, we displayed the pattern of responses to the outcome variables based upon whether respondents thought climate change was a serious issue or not (Figure 2). Below are similar plots for other groupings related to our questions on climate skepticism, awareness and ideology. The figures share a similar pattern to those in the main text.

Figure 1: Distribution of outcome variables conditional upon whether respondents believe or do not believe in anthropogenic climate change.

\section{Distribution of Outcomes}

$\begin{array}{ll}\text { 2) Behavioural Intentions } & 3 \text { ) Environmental Citizenship }\end{array}$

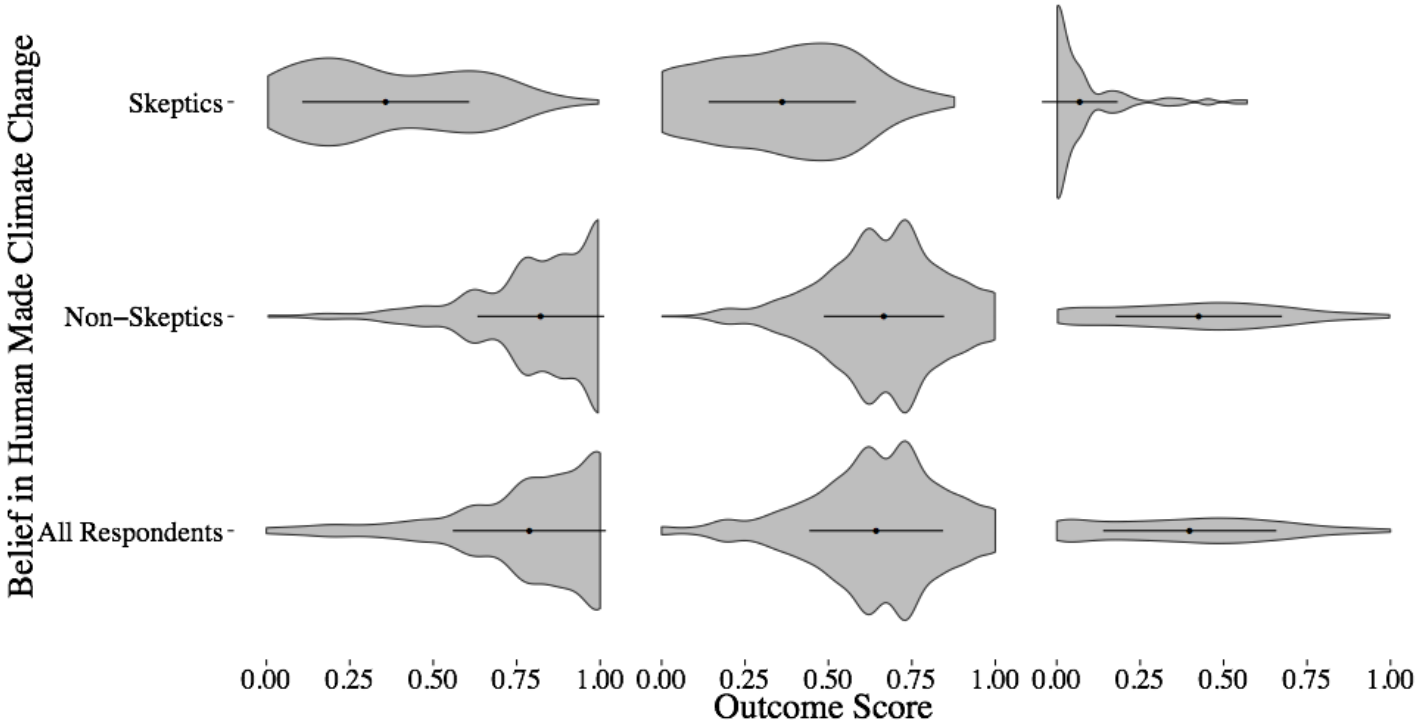

Figure 2: Distribution of outcome variables conditional upon respondents' beliefs regarding the scientific consensus on climate change.

1) Policy Support

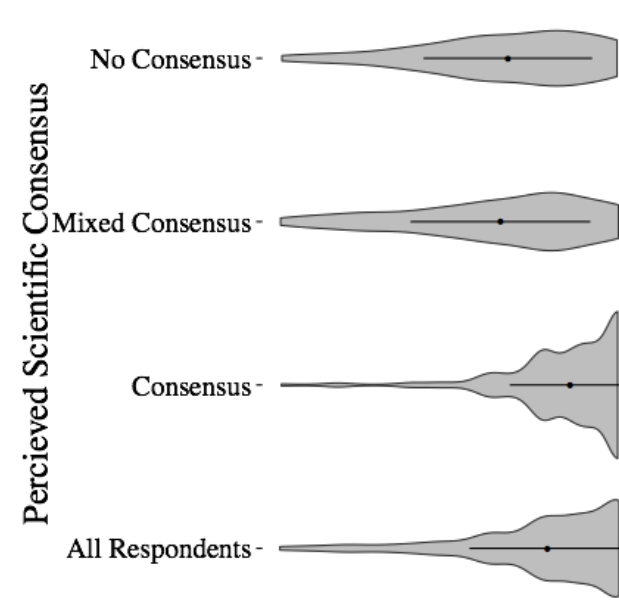

Distribution of Outcomes

$\begin{array}{lll}\text { 2) Behavioural Intentions } & 3 \text { ) Environmental Citizenship }\end{array}$
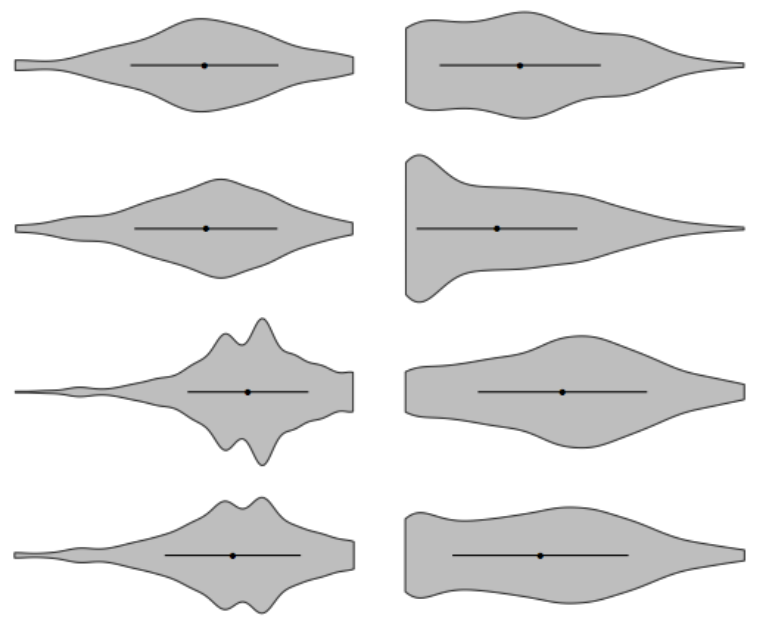
Figure 3: Distribution of outcome variables conditional upon respondents' political

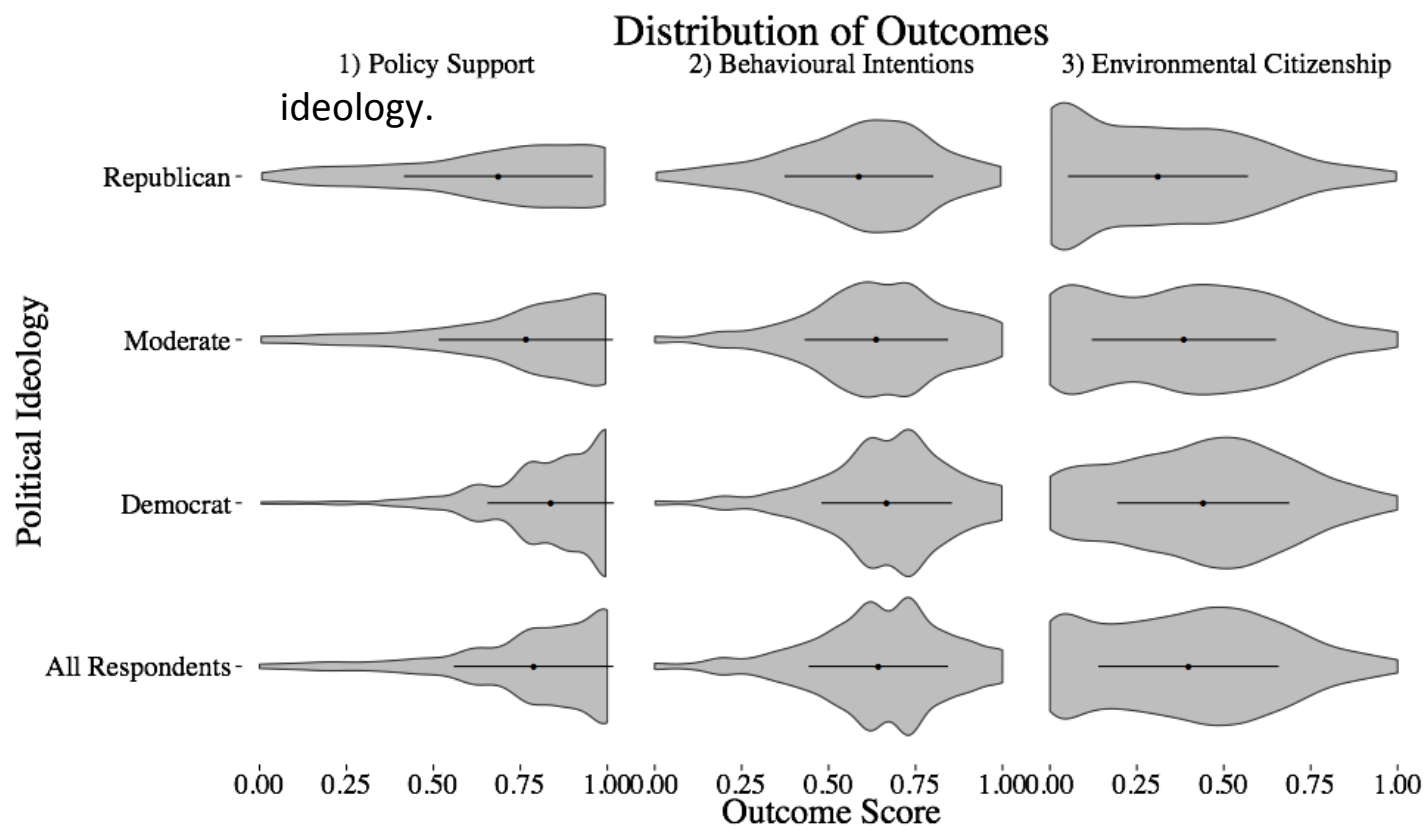

Figure 4: Distribution of outcome variables conditional upon respondents' frequency of thought about climate change.

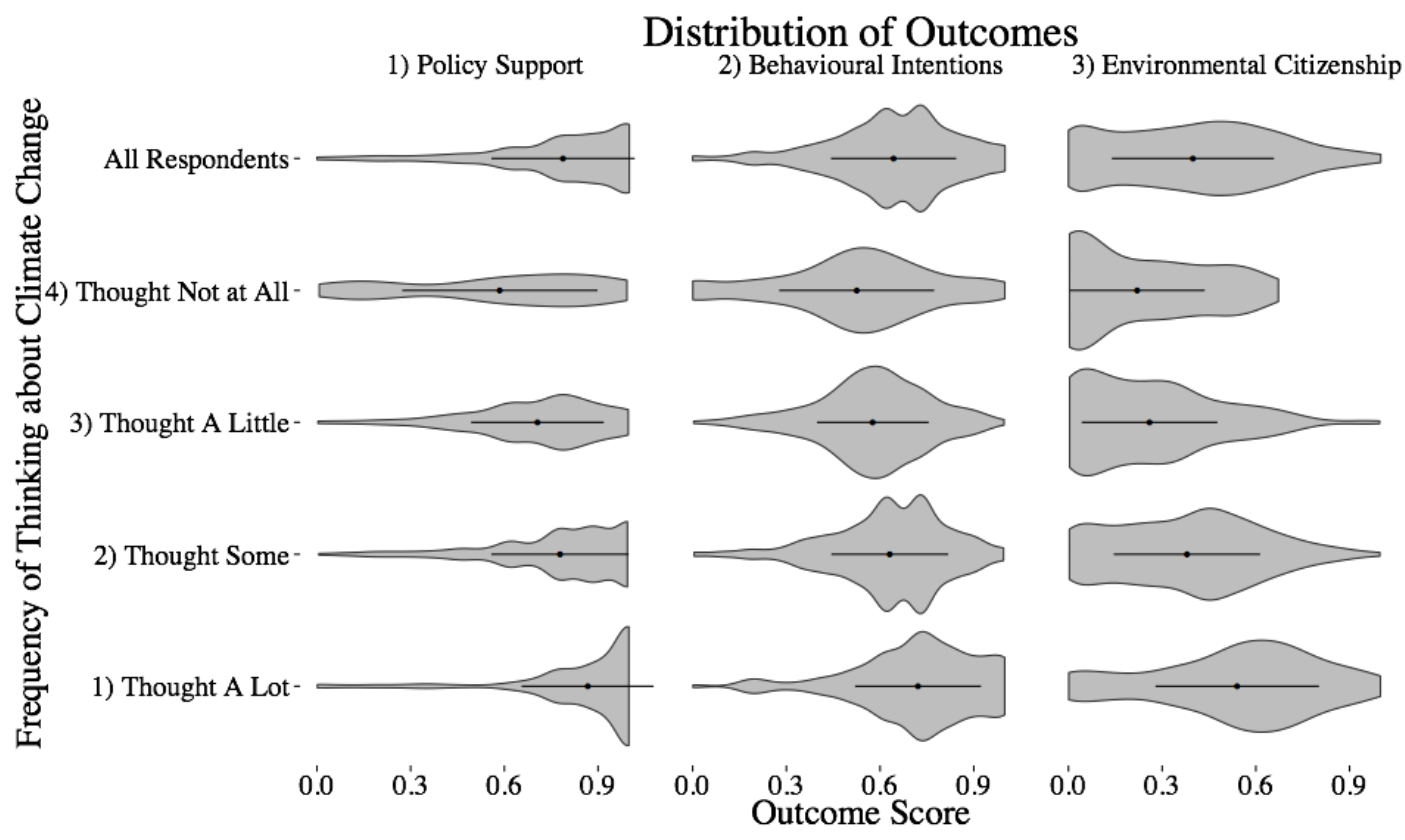


We also examine whether the estimated effect of the treatments change dependent upon the time a respondent took in participating within the experiment. It is possible that framing effects could occur for those who reflected longer on the provided texts, as they may better internalise the frame. ${ }^{8}$

To do so we specify interaction effects in the regression models for estimating the effects of treatments. We allow the treatment effect to be conditional upon: 1) the amount of time a respondent took to complete the survey (linear effect) 2) the cubic polynomial of time that a respondent took to complete the survey (non-linear effect).

Figures 5 - 10 display these estimated conditional treatment effects, ranging from the 5th to 95th percentile of time to complete the survey. As the figures show there is no systematic pattern regarding the effects of treatments being conditional upon the length of time taken on the survey. Therefore we do not find evidence suggesting that there is a stronger treatment effect for those who took more time to reflect upon the treatment.

Figure 5: Treatment effects conditional upon time taken to complete the survey for the environmental citizenship outcome in experiment 1 . The left panel assumes a linear conditional effect, the right panel allows for non-linear conditional effects.
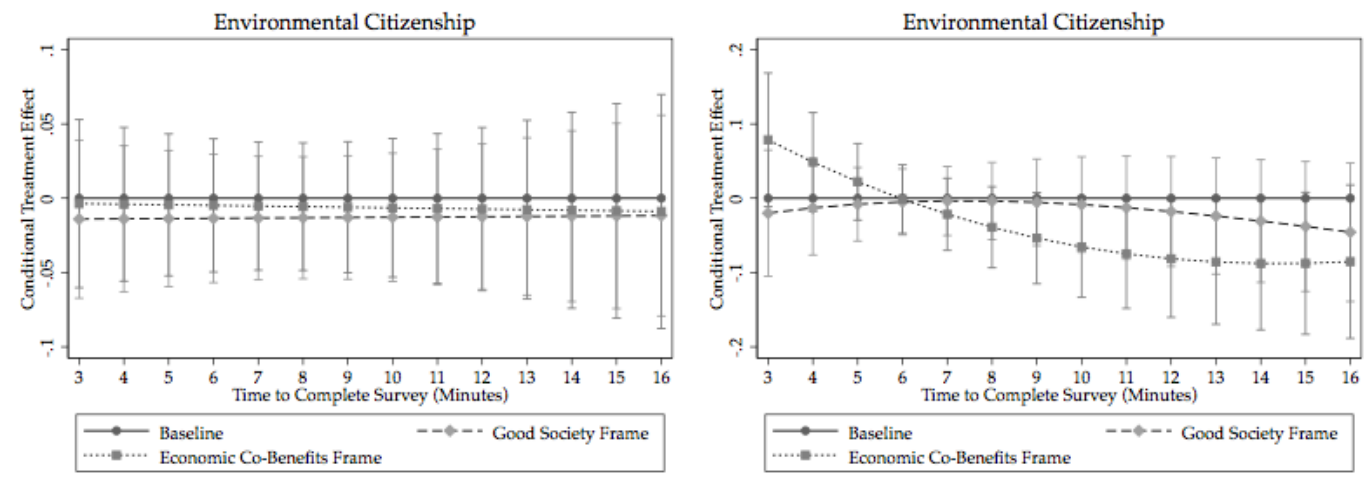

\footnotetext{
${ }^{8}$ We thank an anonymous reviewer for this comment.
} 
Figure 6: Treatment effects conditional upon time taken to complete the survey for the policy support outcome in experiment 1 . The left panel assumes a linear conditional effect, the right panel allows for non-linear conditional effects.
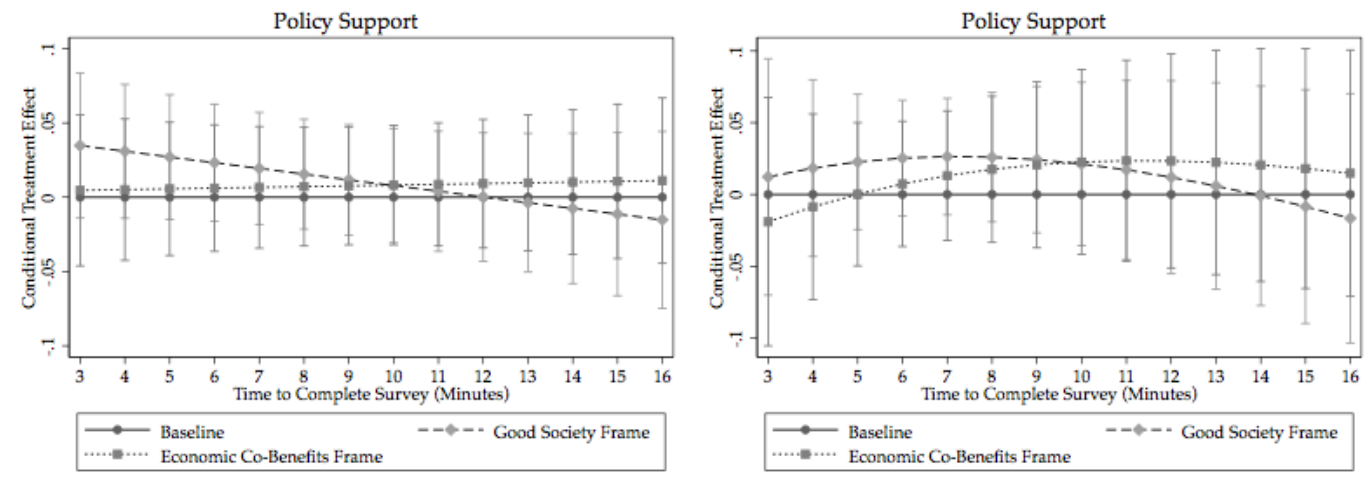

Figure 7: Treatment effects conditional upon time taken to complete the survey for the behavioural intentions outcome in experiment 1 . The left panel assumes a linear conditional effect, the right panel allows for non-linear conditional effects.
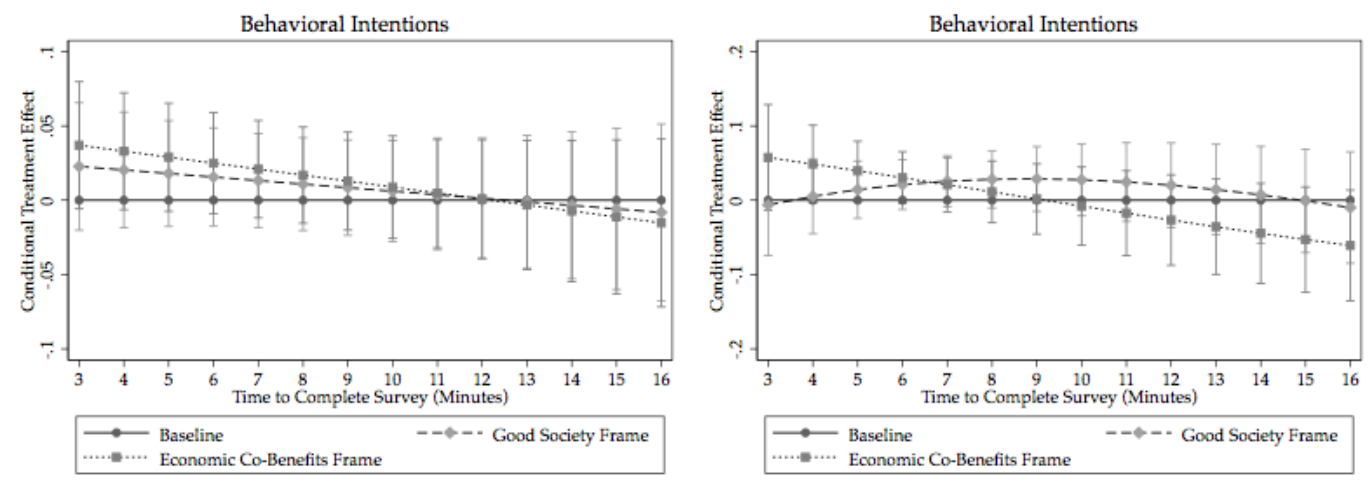
Figure 8: Treatment effects conditional upon time taken to complete the survey for the environmental citizenship outcome in experiment 2 . The left panel assumes a linear conditional effect, the right panel allows for non-linear conditional effects.
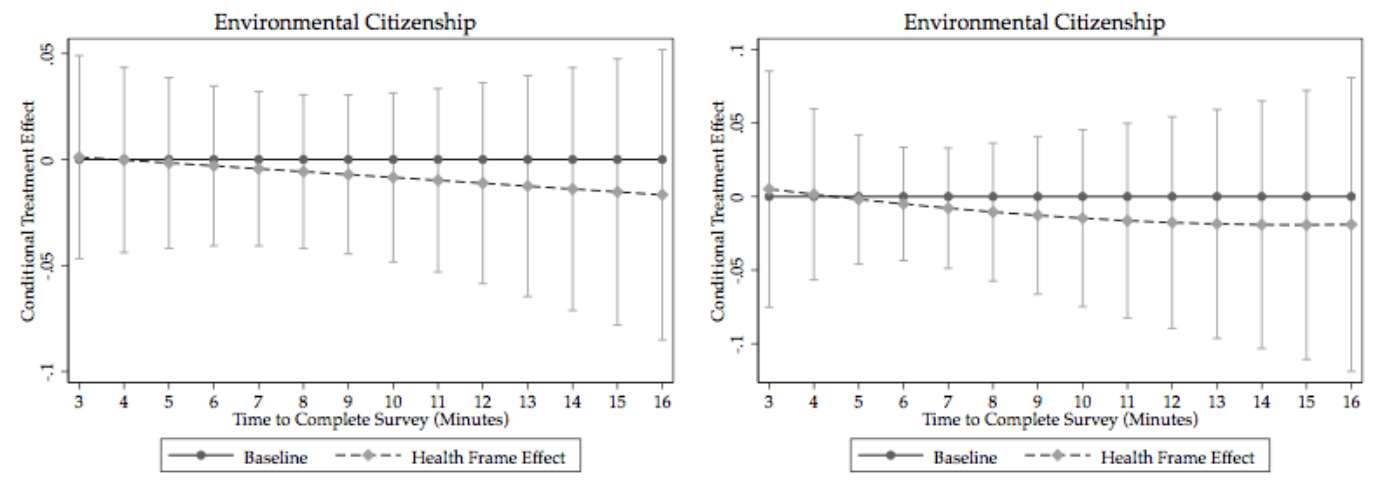

Figure 9: Treatment effects conditional upon time taken to complete the survey for the policy support outcome in experiment 2 . The left panel assumes a linear conditional effect, the right panel allows for non-linear conditional effects.
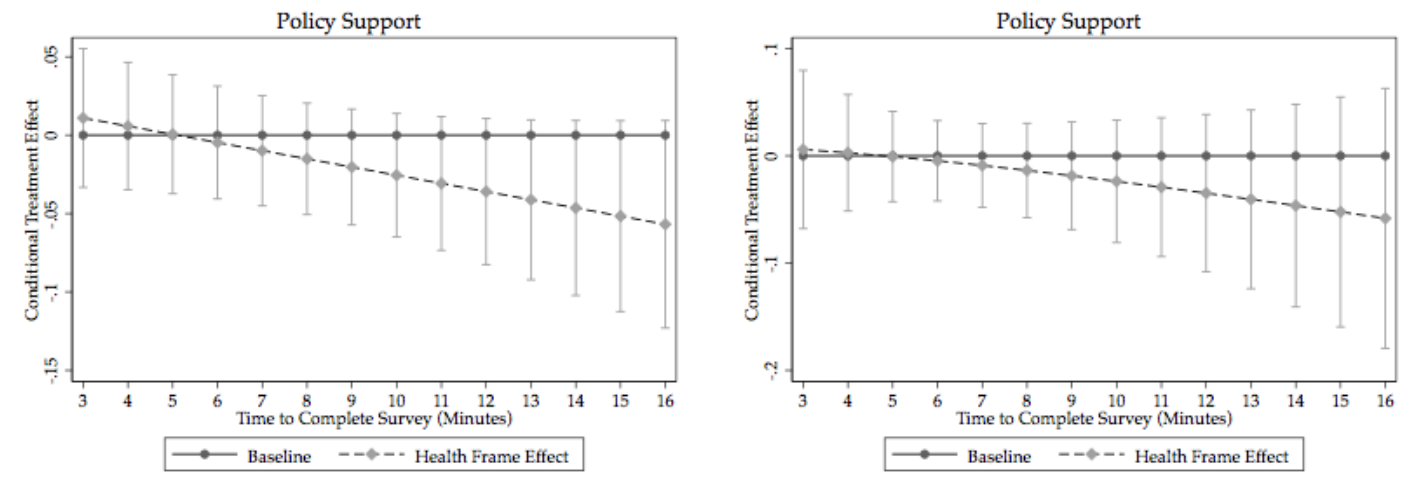
Figure 10: Treatment effects conditional upon time taken to complete the survey for the behavioural intentions outcome in experiment 2 . The left panel assumes a linear conditional effect, the right panel allows for non-linear conditional effects.
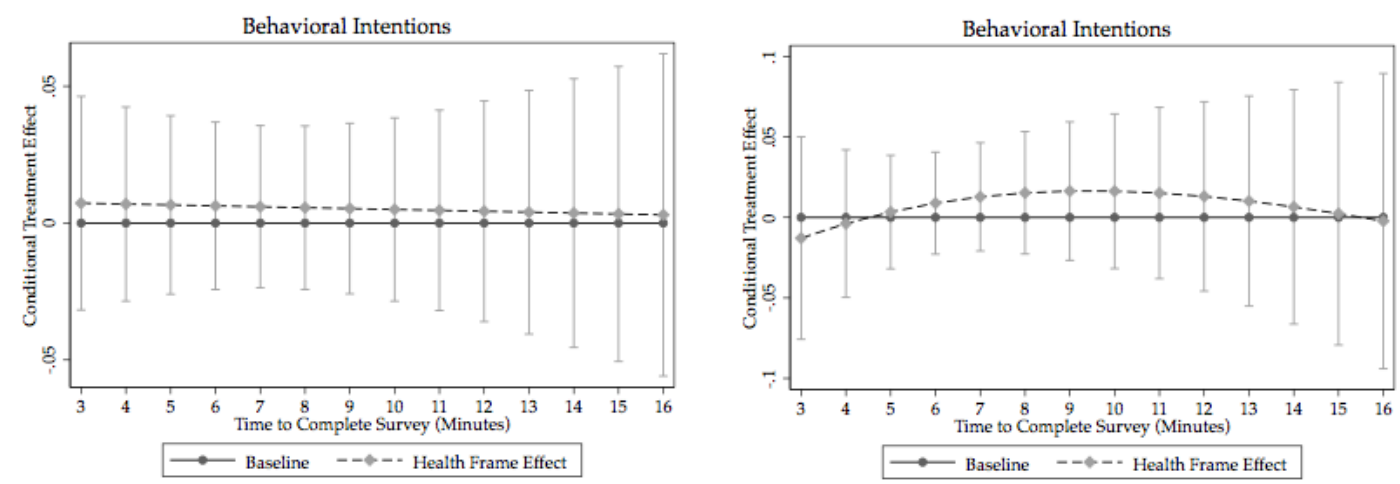


\section{References}

Amazon Mechanical Turk. 2012. "Amazon Mechanical Turk." Available at: http://www.mturk.com/mturk/welcome (accessed 17 Oct 2014).

Berinsky AJ, Huber GA and Lenz GS. 2012. "Evaluating Online Labor Markets for Experimental Research: Amazon.com's Mechanical Turk." Political Analysis 20(3):351-368.

Clifford S., Jewell RM, and Waggoner PD (2015) Are samples drawn from Mechanical Turk valid for research on political ideology? Research \& Politics 2 (4) DOI: $10.1177 / 2053168015622072$

Hanmer, MJ and Kalkan, KO (2013) Behind the Curve: Clarifying the Best Approach to Calculating Predicted Probabilities and Marginal Effects from Limited Dependent Variable Models. American Journal of Political Science 57(1): 263277

Mason, W. and Suri, S. 2012. Conducting Behavioral Research on Amazon's Mechanical Turk. Behavior Research Methods 44(1):1-23.

Mullinix KJ, Leeper TJ, Druckman JN and Freese J (2015) The Generalizability of Survey Experiments Journal of Experimental Political Science 2(2): 109-138

Ross J., Irani L., Silberman M. et al. 2010. "Who are the Crowdworkers?: Shifting Demographics in Mechanical Turk." Proceedings of the 28th of the International Conference Extended Abstracts on Human Factors in Computing Systems. ACM, 2863-2872. 